\title{
DLOUHODOBĚ UDRŽITELNÝ ROZVOJ, UDRŽITELNÝ ÚSTUP, NEBO ROZVRAT?
}

\author{
PAVEL NOVÁČEK
}

\section{Úvod}

„Je to malý krok pro člověka - a velký skok pro lidstvo.“ To byla slova prvního člověka, Neila Armstronga, který stanul 21. července 1969 na Měsíci. Let Apollo 11 a vstup člověka na mimozemské těleso by nám měly připomínat, že má-li člověk vizi a vůli ji uskutečnit, dokáže veliké věci.

Dnes potřebujeme také odvážnou vizi, jak dál. A snad ještě více potřebujeme dostatek vůle takovou smysluplnou vizi vytrvale prosazovat. Projekt Apollo není jediným příkladem pozitivní vize proměněné v konkrétní a úspěšný čin. Dalším známým prríkladem je Marshallův plán, nebo-li velkorysý Program evropské obnovy, který napomohl tomu, aby se západní Evropa stala oázou prosperity a míru.

V 70. letech 20. století Světová zdravotnická organizace vyhlásila válku pravým neštovicím a během jediného desetiletí ji dovedla do vítězného konce. A nebo starší příklad - objevení a kolonizace Severní Ameriky. Na to, jak jsme se chovali k původním obyvatelům, hrdí být nemůžeme, ale představme si to obrovské množství energie, které byli lidé schopni vyvinout na přeměnu divočiny do dnešní podoby.

V současnosti stojíme před podobnou výzvou, ovšem mnohem většího, globálního rozsahu. Jsme konfrontováni s velikou bídou ve světě. Před čtyřiceti lety jsme dokázali vyslat lidi na Měsíc, ale zabránit tomu, aby lidé umírali hladem, neumíme dodnes. Životní prostředí je $\mathrm{v}$ mnoha regionech poškozeno či přímo devastováno. Nenávratně nám vlivem člověka mizí živočišné a rostlinné druhy. Počet obyvatel na zemi pořád ještě roste a zvyšuje se tak antropogenní tlak na ekosystémy a na čerpání př́rodních zdrojů. Ale nejzásadnější pro vývoj v první polovině 21. století budou asi tři relativně nové a velmi komplikované megavýzvy - klimatické změny, ropný zlom a terorismus. Později se o nich zmíníme podrobněji.

Potřebujeme tedy vizi, jak dál, ale možná více, než jen to. Potřebujeme hledat a nacházet, slovy V. Frankla „vưli ke smyslu“. Viktor Frankl [2006], rakouský psychiatr a zakladatel logoterapie, který jako jediný z rodiny přežil nacistický koncentrační tábor, k tomu říká, že společnost blahobytu, popř́ípadě stát blahobytu, jsou schopny uspokojit prakticky všechny potřeby člověka, přičemž jednotlivé potřeby konzumní společnost teprve vytvář́. Pouze jedna potřeba vychází naprázdno a to je „vůle ke smyslu“, to znamená potřeba najít ve svém životě nebo snad lépe řečeno v každé jednotlivé životní situaci smysl - a oddat se mu, naplnit jej.

Téměř čtvrt století se rozvíjí koncepce tzv. udržitelného rozvoje, jako pokus reagovat pozitivním a demokratickým způsobem na vyhrocující se globální a environmentální 
problémy. Nakolik je však tato cesta perspektivní v dnešním multipolárním světě, kdy přiliš mnoho aktérů (států, nadnárodních korporací,...) prosazuje své individuální zájmy, je otázkou. Domnívám se, že odpověd', alespoň v hlavních rysech, se dozvíme v průběhu první poloviny 21 . století.

\section{Udržitelný rozvoj}

Zprávy Římskému klubu a některé další globálně orientované zprávy sedmdesátých a počátku osmdesátých let 20. století přesvědčivě ukázaly, že exponenciální nárůst výroby a spotřeby v konečném ekosystému Země není dlouhodobě udržitelný. ${ }^{1}$ Stávalo se také stále zřejmějším, že je nutné respektovat odlišný pohled zemí rozvinutých a rozvojových, kdy rozvojové země vcelku oprávněně vyjadřovaly svoji touhu nejprve dosáhnout lepších podmínek k životu a až pak se případně omezovat $s$ ohledem na únosnou kapacitu ekosystémů.

V roce 1983 proto požádal generální tajemník OSN Javier Perez de Cuellar ministerskou předsedkyni Norska (dříve ministryni životního prostředí) Gro Harlem Brundtlandovou, aby vytvořila mezinárodní komisi, která by se pokusila o zdánlivě nemožné - přijít s návrhy, jak umožnit lidem a celým národům rozvoj při zachování funkčních ekosystémů a zdravého životního prostředí člověka. Výsledkem čtyřletého úsilí vzniklé Komise OSN pro životní prostředí a rozvoj byla zpráva „Naše společná budoucnost“ (nazývaná též neoficiálně „Zpráva Brundtlandové“), publikovaná v roce 1987. Klíčovým pojmem této pravděpodobně nejvýznamnější zprávy OSN 80. let 20. století se stal „udržitelný rozvoj“ (sustainable development), který na sklonku minulého tisíciletí a počátku 21. století doslova „hýbal světem“.

Udržitelný rozvoj je podle Komise OSN pro životní prostředí a rozvoj [The World Commission on Environment and Development 1987] takový rozvoj, který uspokojuje potřeby současnosti bez ohrožení potřeb budoucích generací uspokojovat jejich vlastní potřeby. V nejširším smyslu je strategie udržitelného rozvoje zaměřená na prosazování harmonie mezi lidskými bytostmi a mezi lidstvem a př́rodou.

Tato definice je antropocentricky orientovaná (uspokojování potřeb člověka), to by však tolik nevadilo. Především je ale natolik vágní a „všeobjímajíci“, že s ní prakticky nejde nesouhlasit. Jejím největším nedostatkem je však to, že se ani nepokouší definovat lidské potřeby.

Herman Daly [1996] upozornil, že ve druhé polovině 90. let 20. století přestala vágnost pojmu „udržitelný rozvoj“ sloužit jako platforma konsenzu a místo toho se stala zdrojem neshod. Ten, komu se podaří prosadit vlastní definici pojmu udržitelný rozvoj, vyhraje podle Dalyho velký politický zápas a získá klíče k naší společné budoucnosti.

\footnotetext{
Jednalo se nejen o první zprávu pro Rímský klub „Meze růstu“ [Meadows, Meadows, Rangers 1972], ale také o některé dalš́ zprávy: „Lidstvo v bodě obratu“ [Mesarovi, Pestel 1976], „Přetvoření mezinárodního pořádku“ [Tinbergen 1976], „Konec věku plýtvání [Gabor 1977], „Cíle pro lidstvo“ [László 1977], „Cestovní mapa do budoucnosti“ [Hawrylyshyn 1980]. Mimo aktivity Rímského klubu a jeho spolupracovníků to byly nap̌r. publikace „Mít nebo být“ od Ericha Fromma [1976], „Bod obratu“ od Fritjofa Capry [1982], „Malé je milé od Ernsta Friedricha Schumachera [1973], „Gaia - nový pohled na Zemi“ od Johna E. Lovelocka [1979], „Global 2000, zpráva pro prezidenta“ od Geralda O. Barneyho [1980] a další.
} 
Bývalý československý federální ministr životního prostředí Josef Vavroušek [1993], definoval udržitelný rozvoj jako rozvoj, který usiluje o ideály humanismu a harmonie vztahů mezi člověkem a př́rodou. Je to způsob života, který hledá rovnováhu mezi svobodami a právy každého jedince a jeho odpovědností vůči jiným lidem a prrírodě jako celku, a to včetně odpovědnosti vůči budoucím generacím.

$\mathrm{Na}$ Karlově univerzitě v Praze se teorií udržitelného rozvoje soustavně zabývá Ivan Rynda [2000], který udržitelný rozvoj vymezuje jako komplexní soubor strategií, které umožňují pomocí ekonomických nástrojů a technologií uspokojovat sociální potřeby lidí (materiální a duchovní), při plném respektování environmentálních limitů. Aby to bylo v globálním měřítku současného světa možné, je nutné je podle něj nutné redefinovat na lokální, regionální i globální úrovni jejich instituce a procesy.

Koncept udržitelného rozvoje je rozvíjen již čtvrt století a přesto se nezbavil značné vágnosti ${ }^{2}$, která právě pramení ze snahy postihnout a reagovat na velmi komplexní globální (nejen environmentální) problémy. Hlavní slabiny konceptu udržitelného rozvoje výstižně charakterizoval Ján Topercer ml. [Mederly, Topercer, Nováček 2004]. Tvrdí, že udržitelný rozvoj předpokládá druh rozvoje, který neohrozí možnosti budoucích generací uspokojovat jejich vlastní potřeby, viděné ovšem z pohledu generace současné. Takto vnímaný rozvoj je vyhlašován za žádoucí, čímž se orientuje spíše na předepisování, než na předvídání. Pro předepisování však podle Topercera tento koncept příliš spolehlivý základ nemá, nebot:

- idea o univerzální hierarchii potřeb není dostatečně empiricky podložena [Smelser, 1994], což platí nejen v prostoru (geograficky), ale možná ještě více i v čase;

- také naše normy a standardy toho, co je optimální či žádoucí, se vyvíjejí v čase;

- je těžké operacionalizovat současné potřeby a možnosti a jejich uspokojování, natož ty budoucí, zejména díky enormní neurčitosti některých předpokladů a faktů;

- je extrémně těžké až sporné operacionalizovat a kvantifikovat celou řadu okrajových podmínek, proměnných a jejich prahových hodnot, v nichž se udržitelný vývoj ekosystému může změnit na neudržitelný;

- je těžké udržitelný rozvoj konceptualizovat (proto také existuje takové množství různých přístupů a chápání), natož ještě navrhovat testovatelné hypotézy a na jejich základě budovat teorii udržitelného rozvoje, která v tomto smyslu vlastně stále neexistuje.

Z pojmu (trvale) udržitelný rozvoj navíc dle Topercera „vyčuhuje“ jedna z nápadných podob univerzální touhy většiny lidí, touhy dívat se na svět z pohledu „Božího oka“ [Putnam, Rorty 1997], které je schopné nezkresleně vidět a vyhodnocovat nejen potřeby a možnosti minulých a současných, ale i budoucích generací. Byl by to pravděpodobně velmi lákavý pohled pro věřící i nevěřící, jen jestli při něm ambice poněkud nepřesahují naše možnosti a schopnosti (více než žádoucí je tedy dưrazná korekce popperovským

2 Právě kvůli určité vágnosti pojmu jsou intenzívně rozvíjeny indikátory udržitelného rozvoje a konstruovány různé agregované indexy, které by umožnily exaktně měřit, nakolik v jednotlivých oblastech života (životní prostředí, čerpání zdrojů, ekonomický rozvoj, sociální oblast, fungování státu,...) směřujeme či nesměřujeme $k$ udržitelnosti. 
požadavkem intelektuální skromnosti a karteziánskou metodickou skepsí). Udržitelný rozvoj tedy můžeme pracovně zařadit do kategorie „science \& art“, tedy mezi obory na pomezí vědy a umění.

Koncept udržitelného rozvoje rozhodně není dokonalý a není vědeckou teorií, nicméně nemáme (alespoň zatím) nic lepšího, jak se pokusit na dnešní vyhrocující se problémy globálního rozsahu reagovat.

Máme (jednotlivci i společnost) v principu vlastně tři možnosti, jak na současné globální výzvy reagovat:

1. Můžeme problémy podceňovat, bagatelizovat, či přímo ignorovat. ${ }^{3}$ Mưžeme uprímně věřit, nebo si nalhávat, že situace (důsledky klimatických změn, vysoké populační přírůstky v rozvojových zemích, vyčerpání zdrojů, chudoba atd.) není vážná a není třeba se znepokojovat. $Z$ toho však logicky plyne, že není třeba reagovat a vše může zůstat při starém, běžet v zaběhnutých kolejích. Tím se však problémy nevyřeší. Naopak, odkládáním účinné akce se dále vyhrocují a my plýtváme možná tím nejvzácnějším a „vyčerpatelným“ zdrojem, a tím je čas.

2. Mưžeme uznat vážnost problémů, aniž bychom se ovšem pokusili o jejich řešení. Obáváme se katastrofy, ale nevěříme, že by naše úsilí mohlo mít smysl, že bychom sami mohli pro záchranu něco udělat. Proto zůstáváme pasivní, „svěřujeme se osudu“, doufáme, že se to „samo“ nějak vyřeší. A nebo, v horším případě, se chováme podle hesla „po nás potopa“, snažíme se individuálně urvat ještě pro sebe co nejvíce slastí, než bude vše ztraceno. Potlačujeme tak pud sebezáchovy a chováme se krutě především vưči svým dětem, vůči budoucím generacím.

3. Můžeme se aktivně pokusit o ovlivnění a změnu dnešních nepříznivých trendů, o formulování a prosazování alternativní, pozitivní a demokratické vize rozvoje společnosti. Jsem přesvědčen, že vize udržitelného rozvoje, při vědomí všech jejích nedokonalostí, je takovou nadějí. Nikdo nám ovšem nedá odpověd’ na otázku: „Jaká je šance na úspěch?" Ta šance může být osmdesátiprocentní, nebo také jednoprocentní, a přesto bychom se o ni měli pokusit. Protože nejsme ani tak jako jednotlivci odpovědní za výsledek (ten můžeme obvykle ovlivnit velmi limitovaně), ale jsme určitě všichni odpovědni za své úsilí, kolik a čemu věnujeme svého času, energie a schopností.

Zkusme nyní shrnout hlavní myšlenky obsažené v definicích a principech udržitelného rozvoje do čtyř zobecňujících základních požadavků.

\section{Požadavek, aby všichni lidé na Zemi mohli uspokojovat své (alespoň základní) potřeby.}

Už s definicí základních lidských potřeb je potíž. K prostému přežití potřebujeme jídlo, vodu, ošacení a př́istřeší. Jenže trvale jen přežívat se samozřejmě nedá. Přesto, bohužel, kolem jedné miliardy lidí na světě akutně hladoví a 1,2 miliardy lidí nemá přístup $\mathrm{k}$ nezávadné pitné vodě. $V$ rozvinutých zemích bychom se jistě neradi smiřovali s pokrytím pouze těch nejzákladnějších potřeb umožňujících přežití. Kde je však hranice lid-

\footnotetext{
Učebnicovým př́kladem takového přístupu jsou postoje českého prezidenta Václava Klause k problematice klimatických změn.
} 
ských potřeb? Pravděpodobně „V nekonečnu“. Existují tedy hranice oprávněných lidských potřeb? A liší se v čase a prostoru?

Známou a široce přijímanou je hierarchie (pyramida) lidských potřeb Abrahama Maslowa [1954]:

- Základní tělesné, fyziologické potřeby.

- Potřeba jistoty a bezpečí.

- Sociální potřeby (potřeba sounáležitosti a lásky).

- Potřeba uznání a úcty.

- Potřeba seberealizace.

Ani Maslowova hierarchie lidských potřeb nám však neumožňuje stanovit nějakou rozumnou limitní hranici pro lidské tužby, které bývají vnímány jako potřeby či snad dokonce jako něco, na co máme právo.

Komunistická ideologie měla líbivé heslo, které nikdy nedokázala (a ani nemohla dokázat) naplnit: „Každý podle svých schopností, každému podle jeho potřeb.“ Je však oprávněnou potřebou automobil, soukromá jachta, turistický výlet na oběžnou dráhu?

Myslím, že požadavek na uspokojování potřeb v definici Světové komise pro životní prostředí a rozvoj je sice líbivý, ale nesplnitelný a dokonce nedefinovatelný. Logičtější a správnější se mi jeví podmínit uspokojování lidských potřeb respektováním únosné kapacity ekosystémů při zachování přírodních hodnot a biologické rozmanitosti pro současné i budoucí generace, jak to uvádí např. definice udržitelného rozvoje Evropského parlamentu ${ }^{4}$. Tedy ještě jednou - základním požadavkem udržitelného rozvoje by nemělo být uspokojování lidských potřeb, ale respektování únosné kapacity ekosystémů, od které se aktivity lidí v jednotlivých regionech i časových obdobích musí odvíjet.

\section{Požadavek práv budoucích generací uspokojovat svoje potřeby.}

Toto je velká a nová výzva. V historii různé skupiny obyvatel usilovaly (at̉ už násilnými, nebo nenásilnými prostředky) za prosazení svých práv - otroci, nevolníci, kolonizované národy atd. V současnosti jde o to, budeme-li schopni respektovat práva těch, kteří tu ještě nejsou, ale budou - našich dětí a všech následujících generací. Toto obecné konstatování můžeme konkretizovat pomocí tří principů Hermana Dalyho a Johna Cobba [1989], jak dlouhodobě udržitelně využívat přírodní zdroje a ekosystémy Země:

a) Míra užívání obnovitelných zdrojů (les, rybí populace,...) nepřekročí míru jejich regenerace.

b) Míra užívání neobnovitelných přírodních zdrojů (např. fosilní paliva) nepřekročí míru, jakou budou rozvíjeny substituující obnovitelné zdroje.

4 Evropský parlament definuje udržitelný rozvoj jako takový rozvoj, který přináší zlepšování životní úrovně a blahobytu lidí v mezích kapacity ekosystémů při zachování prírodních hodnot a biologické rozmanitosti pro současné a př́šsí generace. 
c) Míra emisí škodlivin do životního prostředí nedosáhne hranice asimilačních schopností prostředí (a nepřesáhne tedy únosnou kapacitu ekosystémů).

\section{Požadavek respektování práv ostatních živých bytostí}

Je to další velká výzva, kterou jsme si ve 20. století při „dobýváni“ přírody prŕliš nepřipouštěli. Podobně jako u prvního požadavku udržitelného rozvoje, i zde nedokážeme definovat optimální stav. Má člověk využít svého dominantního postavení mezi ostatními živými tvory a jednat jako „pán tvorstva“, nebo má být spíše zodpovědným správcem této planety? Nebo máme ostatní živé bytosti považovat za sobě rovné (ponechme ted’ stranou, že tento radikální požadavek by nebyl prakticky realizovatelný)?

Měli bychom mezi jednotlivými druhy živočichů rozlišovat podle toho, na jakém místě se nacházejí v evolučním vývoji?

Jsou to otázky, na které neumíme odpovědět a určit jednoznačně, co je dobře a co špatně. Přesto bychom tyto výzvy neměli ignorovat a odpovědi postupně formulovat, byt to může trvat desetiletí a možná déle. Měli bychom se postupně přibližovat harmonii vztahů mezi člověkem a živou i neživou přírodou, jak uvádí ve své definici Josef Vavroušek. Plné harmonie asi nedosáhneme nikdy. Vždy však můžeme mít úctu k životu a př́rodě ve smyslu odkazu Alberta Schweitzera.

\section{Požadavek učení se z budoucnosti}

Tento požadavek z uvedených definic explicitně nevyplývá, přesto jsem přesvědčen, že je pro naplňování udržitelného rozvoje nepostradatelný. Po celou svou historii se člověk učil z minulých zkušeností svých nebo svých bližních. Tento model fungoval po tisíciletí dobře, pokud důsledky našich činů (a omylů) byly prostorově i časově limitované. Nyní máme díky vědeckému poznání a technologickému rozvoji takové možnosti, že případné omyly mohou mít drastické důsledky, at už se jedná např. o mírové i vojenské využití jaderné energie, geneticky modifikované organismy, klimatické změny atd. Proto je nezbytné učit se nejen $\mathrm{z}$ minulosti, ale také $\mathrm{z}$ možných budoucností a podle toho usměrňovat své chování a jednání. ${ }^{5}$

\footnotetext{
Je možné si to celé přibližit na následujícím prŕíkladu: Přirovnejme lidskou společnost k posádce automobilu, která jede v noci horskou silnicí. Dokud jel automobil velmi pomalu, bylo možné jet se zhasnutými světly a rrídit se pohledem do zpětného zrcátka. Jak se však automobil pohybuje stále rychleji (resp. celá lidská společnost díky vědecko-technickému rozvoji se vyvíjí stále rychleji), je nutné dívat se dopředu, ne dozadu. A je vhodné zapnout reflektory. Čím rychleji se pohybujeme, tím lepší světla (tedy schopnost vidět dopředu) potřebujeme. Při malé rychlosti automobilu nemá náraz do svodidel vážné následky. Při vysoké rychlosti však ,jízda naslepo“ může mít tragické následky.

V tomto přirovnání je možné si přiblížit i princip předběžné opatrnosti. Předpokládejme, že v dáli se do noci před automobilem tyčí temná hora. Cást posádky tvrdí, že tam určitě bude tunel a je proto možné „šlápnout na plyn“ a jet stále rychleji. Druhá část posádky ovšem tvrdí, že tam tunel nemusí být, i když to jistě zatím neví nikdo. Právě proto je však třeba přibrzdit a pohybovat se kupředu obezřetně.
} 


\section{Co když to nedopadne dobře?}

Máme životní úroveň, o jaké se našim předkům ani nesnilo. Za našeho života vymřela čtvrtina všech živočišných druhů. Spotřebovali jsme více př́rodních zdrojů, než lidstvo za celou předcházející historii. A žijeme na počátku století, ve kterém je konec naší civilizace pravděpodobnější, než kdykoli předtím. ... Jak žít tváŕí v tvář zániku?

Jaroslav Kalous

Měli bychom připustit a promyslet alternativu, že úsilí o dlouhodobě udržitelný rozvoj se nepodaří (pro nedostatek odhodlání, času, nebo obojího) a lidské společenství projde velkým civilizačním otřesem. Byl bych rád, kdyby se jednou ukázalo, že následující úvahy měly povahu sebedestruktivního proroctví, tedy že aspoň trochu přispěly $\mathrm{k}$ tomu, aby špatný konec nenastal.

Ze všech globálních problémů, které jsou v odborné literatuře zmiňovány, lze vybrat tř̌i „megaproblémy“, které jsou obzvláště nebezpečné a navíc se navzájem ve svém působení posilují. Jsou to populační růst, chudoba a ohrožení životního prostředí.

Na Zemi nyní žije sedm miliard obyvatel a absolutní počet lidí narůstá, i když míra př́růstku se mírně snižuje. Mezi environmentalisty je celkem jednoznačná shoda, že dnešní počet lidí na planetě nemůže dosáhnout životní úrovně nejbohatších států, protože na to prostě není dostatek zdrojů a ekosystémy takovou zátěž neunesou. Populační růst je kritický zejména v některých regionech, např́klad v muslimských zemích Blízkého východu. Př́liš mnoho mladých lidí je pak odsouzeno k životu v chudobě, bez zaměstnání a bez perspektivy, což vytváří výbušnou situaci. Čím více lidí na planetě, tím více chudých a tím větší zátěž a následná devastace životního prostředí.

Chudoba, přesněji řečeno bída ${ }^{6}$, provází člověka od nepaměti. Přitom nikdy v historii jsme neměli tak mocné prostředky, abychom se s ní vypořádali. A nikdy v historii bídou netrpělo ( $v$ absolutním vyjádření) více lidí.

V roce 2011 bylo na světě 1210 miliardářu (vyjádřeno $v$ amerických dolarech), jejich počet rychle narůstá zejména v rozvíjejících se ekonomikách Číny, Indie a Ruska. Ti vlastnili dvakrát více bohatství, než polovina ( 3,4 miliardy) chudých lidí [Glenn, Gordon, Florescu 2011]. Člověk nemusí být génius, aby mu došlo, že tento stav není ani spravedlivý, ani dlouhodobě udržitelný. Protože chudí lidé mají více dětí, než bohatí, posiluje chudoba populační růst. A samozřejmě také zvyšuje zátěž životního prostředí, protože chudí žijí ze dne na den a nemají sílu ani chut přemýšlet, co nahradí les, který kácí, nebo co se stane s jezerem, do kterého vypouštějí své odpady.

A konečně životní prostředí je komplexní problém s dlouhou setrvačností působení. Některé negativní jevy by odezněly rychle, pokud by přsstala působit př́ícina těchto jevů. Např́klad povrchové vody, pokud je přestanou lidé znečištovat, se zlepší velmi rychle, v řádu dní či týdnů. Narušení ozónové vrstvy potrvá roky, spíše však desítky let poté, co odezní příčina (vypouštění freonů). Ale úbytek biodiverzity, vyhubení druhů rostlin a živočichů „neodezní nikdy, ztráta je nevratná.

6 Chudoba je různými náboženstvími chápána jako ctnost. Jedná se však o dobrovolnou chudobu (tedy dobrovolně vedený velmi skromný život), která člověka vnitřně nedevastuje, ale spíše posiluje. Život v bídě naproti tomu člověka poškozuje po stránce fyzické, psychické i morální. 
Čím větší populační růst, tím více chudoby (bídy) a větší tlak na životní prostředí. Čím větší chudoba, tím zdevastovanější prostředí a vyšší nárůst obyvatel. A čím zdevastovanější prostředí, tím větší chudoba a vyšší populační přírůstky.

Na počátku 21. století se objevily tř̌i méně obecné, o to však aktuálnější problémy, které mohou podlomit obranyschopnost a životaschopnost naší civilizace. Jsou to klimatické změny, terorismus a ropný zlom.

O nebezpečí klimatických změn víme několik desetiletí. Problém je velká míra nejistoty - nevíme, co se přesně děje, jaké to bude mít důsledky a kdo změny působí - jestli více jevy prrírodní nebo antropogenní. Dalším problémem je, že hlad po energii je tak velký, že přes všechny politické proklamace a závazky nejspíše emise skleníkových plynů nebudeme schopni výrazně omezit. Aspoň zatím tomu nic nenasvědčuje.

V poslední době se proto více mluví o potřebě adaptace (přizpơsobení se změnám), ne o potřebě prevence klimatických změn. Tyto změny však z pohledu vyspělé civilizace mohou být drastické a nová rovnováha, která se ustaví, bude trvat desetitisíce, možná statisíce let.

Terorismus také není nový problém a ve 2 . polovině 20. století západní civilizace čelila mnohým lokálním teroristickým skupinám - jen v Evropě to byly např. IRA v Irsku, ETA ve Španělsku, Rudé brigády v Itálii atd. Teprve 11. září 2001 však přineslo zlom. Odhodlání islámských extremistů zničit, nebo alespoň poškodit západní civilizaci je veliké. Fungování rozvinutých společností je vždy do velké míry založeno na důvěre a zejména tu teroristé podlamují (viz bezpečnostní opatření na letištích, ale i veřejných budovách ve Spojených státech a jinde). A pokud západní civilizace nemá dostatečnou vůli a odhodlání se bránit, mohou teroristé uspět.

Ropný zlom dříve či později přijde, resp. možná právě začíná. Čtyřicet let mluvíme o potřebě úspor a přechodu na obnovitelné zdroje, ale ztratili jsme dost možná již př́liš mnoho času. V lednu 2009 hrozilo Evropě, že zůstane nějakou dobu bez ruského plynu. Těžko si představit potíže a zmatek, kdy ceny za fosilní paliva (především ropu) poletí nahoru a dodávky budou nestabilní. Na druhou stranu konečné vyčerpání fosilních paliv (které je zejména $\mathrm{v}$ př́ípadě uhlí a plynu pravděpodobně ještě několik desítek let před námi) je možná to jediné, co dokáže stabilizovat a následně zredukovat emise skleníkových plynů do atmosféry.

Výše zmíněné tři obecné „megaproblémy“ a tř̌i nejaktuálnější současné problémy mohou být tím, co vyspělé civilizaci „zlomí vaz“. I kdybychom měli odhodlání a sílu vypořádat se s jedním problémem, nestačíme reagovat na další, které navíc působí synergicky, tedy vzájemně se podporují a posilují ve svém účinku.

I kdyby některá společnost našla v sobě sílu a odhodlání k odříkání a obětem a k přijetí „krve, potu a slz“ (jako to udělali Britové ve 2. světové válce na Churchillovu výzvu), nebude to stačit, protože na globální problémy by muselo účinně reagovat celé lidské společenství. A není vidět ani náznakem, že bychom toho byli schopni.

Dobrou zprávou je, že život téměř určitě na Zemi nevyhyne. Během posledních 500 miliónů let prošel život na planetě nejméně pěti globálními „katastrofami“, př̀i kterých vždy zmizelo 70-95\% všech rostlinných a živočišných druhů. Přesto evoluce pokračovala k dokonalejším formám života. Život, který vznikl před 3,85 miliardami let, už nebyl ani jednou z povrchu Země vymazán.

Co je v sázce a co může být narušeno až zničeno poměrně snadno, je naše euro-americká civilizace a ve druhém sledu také lidská civilizace obecně. Euro-americká civi- 
lizace je na vrcholu pyramidy, co se týče spotřeby energie, zdrojů a životní úrovně (pokud ji vyjadřujeme materiální spotřebou). Proto je nejohroženější.

Otakar A. Funda [2000] tvrdí, že civilizace zaniká, když:

- ztratila vizi;

- ztratila jistý nepsaný konsenzus o tom, co je správné a co ne;

- náklady potřebné na její udržení v chodu překročí objem výnosů její produkce;

- mechanismy sloužící k udržení jejího fungování v chodu dostoupily takové komplikovanosti, že nejsou opravitelné za provozu;

- se unavila, když vyčerpala svůj rozlet a elán, když se v ní rozhostila rozkladná nálada.

Fundova knížka se jmenuje příznačně „Unavená Evropa umírá“. Nemusí to tak nezbytně být, pokud, slovy Viktora Frankla, dokážeme najít znovu „vưli ke smyslu“. V době velkých krizí se bezpochyby objeví a vyrostou velké osobnosti. Jestli to s naší civilizací dopadne dobře, nebo ne, se pravděpodobně ukáže během první poloviny 21 . století, kdy výše zmíněné problémy vykrystalizují do reálné podoby a ukáží svoji skutečnou sílu. Rozhodující v takové situaci bude nepropadat panice, zoufalství a strachu, který by paralyzoval naše odhodlání problémům čelit, jakkoliv budou děsivé.

Horší, než všechny výše zmíněné problémy a jejich důsledky, dokonce horší, než strach, je ignorování problémů a z toho vyplývající nicnedělání:

Lod'se pomalu potápí, ale zatím nic nepocitujeme, to čeká na naše děti a vnoučata. Oni to moc netuší a slastně si užívají ještě víc, než my. Duchem doby je hédonismus, objektem zájmu to, co je př́ijemné, maximalizace slasti s minimem strasti. Jako bychom si přišli na tuhle planetu jenom užívat, „olizovat život“.

Jaroslav Kalous

\section{Udržitelný ústup nebo klimatický rozvrat?}

Zaměříme se nyní na jedinou, ale dost možná nejvážnější hrozbu - klimatické změny. James Lovelock je známý britský fyzik, který pro NASA zkoumal možnosti života na Marsu. To jej vedlo k přesvědčení, že život na Zemi je nesamozřejmá událost, je jedinečný (i když ne nezbytně jediný ve vesmíru). Před více než 30 lety zformuloval hypotézu Gaia, ve které tvrdí, že systém Země se chová jako jednotný samoregulační systém složený z fyzikálních, chemických, biologických a lidských prvků. Interakce a zpětné vazby mezi jednotlivými komponenty jsou komplexní a vykazují časovou a prostorovou variabilitu na mnoha úrovních. Gaia je tak dle Lovelocka tenká sférická slupka hmoty, která obklopuje žhavý vnitřek. Začíná tam, kde skalnatá vrstva zemské kưry přechází v magma horkého zemského jádra, asi $160 \mathrm{~km}$ pod povrchem, a pokračuje dalších $160 \mathrm{~km}$ ven směrem do vesmíru. Zahrnuje i biosféru a je to dynamický fyziologický systém, který udržuje na naší planetě podmínky pro život už více než tři miliardy let. ... Hypotéza Gaia vidí biosféru jako aktivní, adaptivní systém schopný udržet Zemi v homeostáze [Lovelock 2006]. 
James Lovelock ve svých 86 letech publikoval knihu, ve které shrnuje poznání, ke kterému došel. Sám název je dostatečně výmluvný: „Odplata Gaii“ (Revenge of Gaia, česky vyšlo pod názvem „Gaia vrací úder"). Chce nás vyburcovat, abychom, slovy Jaroslava Kalouse, jen „neolizovali život“, ale postavili se čelem smrtelnému nebezpečí, které představují klimatické změny. Je snad prvním známým autorem, který „překročil Rubikon "7 a tvrdí: že už je pozdě na trvale udržitelný rozvoj, my potřebujeme trvale udržitelný ústup. Vyznavači udržitelného rozvoje i volného trhu se podle Jamese Lovelocka dopouští velkého omylu, když sdílejí víru, že další rozvoj je možný a že Země se udrží ještě nejméně polovinu tohoto století víceméně ve stejném stavu, jako dosud. Očekávat, že udržitelný rozvoj nebo konvenční postup jsou životaschopné metody přístupu, je jako myslet si, že rakovina plic se dá vyléčit tím, že přestaneme kouřit.

Jaké alternativy z toho pro nás podle Lovelocka do budoucna plynou? Prvním požadavkem především je rozpoznat a uznat, že problém existuje. Druhým požadavkem je problému porozumět a vyvodit závěry. ${ }^{8}$ Třetím požadavkem je pak s tím něco udělat.

Nejvíce podle Lovelocka nyní potřebujeme změnit naši povahu a způsob myšlení, stejně jako to dělají kmenové národy, když cítí skutečné smrtelné nebezpečí. Jen tehdy budeme schopni přijmout strádání. Naším úkolem pak bude obrana civilizace, odvrácení chaosu, který by se nás jinak mohl zmocnit.

I kdyby však nastala ponurá budoucnost, globální teplota i hladina oceánů stoupala a civilizace se hroutila, nesmí ti nejodvážnější své úsilí o záchranu možného vzdát. Stejně jako „V dobách temna minulosti“ církevní řády v klášterech uchovávaly to, co je základem naší civilizace. Uschovávaly a předávaly dál těžce vydobyté vědomosti řecké a římské civilizace. Přes všechny naše snahy o udržitelný ústup možná nakonec nebudeme schopni předejít globálnímu úpadku do chaotického světa na zdevastované Zemi, který budou ř́idit krutí váleční vůdci. Pokud by k tomu došlo, měli bychom si podle Lovelocka vzpomenout na skupiny mnichů v horských pevnostech jako Montserrat, nebo na ostrovech Iona a Lindisfarne, kteří tomuto životně důležitému cíli sloužili.

Jednou z možností, jak zmírnit následky katastrofy, je uchovat a předat klíčové vědomosti, které pomohou našim potomkům vybudovat znovu civilizaci, aniž by opakovali naše chyby. Protože, slovy Lovelocka, povyšovat se nad vlastní smrt je lehkomyslnost, ale přistupovat stejně i ke konci civilizace je bezohlednost.

Už jenom z respektu k tak významné osobnosti, jakou James Lovelock je, musíme vzít tuto možnost v potaz a vzít ji dokonce smrtelně vážně. Myslím, že ještě máme nějaký čas svými činy přispět k tomu, aby jeho vize nenastala. Naše schopnosti jsou však omezené a prosazení udržitelného rozvoje může být nad naše síly.

I kdyby však přišel malér a pokus o udržitelný ústup se změnil v anarchii a chaos, stále mají ti slušní, co přežijí, velké poslání: přenést obdobím temna ovoce víry a vědy (poznání) do doby v budoucnosti, jakkoliv vzdálené, která umožní znovu vybudovat civilizaci.

\footnotetext{
Před Lovelockem všichni ostatní autoři, zabývající se globálními problémy, Donellou a Denisem Meadowsovými počínaje, tvrdili: pokud nezměníme své jednání, do třiceti (dvaceti, deseti) let přijde katastrofa. Lovelock první rezignuje na možnost zachování „světlých zítřkư‘ , tuto příležitost jsme dle něj již propásli.

8 Lovelock zdůrazňuje, že jsme polapeni v krutém kruhu pozitivních zpětných vazeb. To, co se děje na jednom místě, velice brzy ovlivní dění jinde. Jsme si nebezpečně nevědomi vlastní nevědomosti.
} 


\section{Infobox: Kořeny krize}

Jak jsme se vlastně dostali do situace, kdy přes všechny úžasné možnosti a vymoženosti vědy a techniky čelíme poprvé $\mathrm{v}$ dějinách velmi závažným a vyhrocujícím se problémům globálního rozsahu?

Z doby industriálního rozvoje v 19. a 20. století přežívá naše zavádějící chápání pokroku. Alvin Toffler [1980] tvrdí, že naše civilizace postavila své chápání pokroku na třech idejích, které nás dovedly ke krizi:

a) vykořistování př́rody a vláda nad ní jsou správné;

b) lidé jsou vrcholným výtvorem evoluce, princip přirozeného výběru (Darwin) se přenáší i do společenského chápání („nejbohatší a nejmocnější jsou i nejschopnější a nejzasloužilejšsí);

c) dějiny nezvratně směřují k lepšímu životu lidstva.

Je pozoruhodné, kolik lidí v různých časových údobích se domnívalo, že př́íčinou krize a úpadku jedince i společnosti je to, co často považujeme za kýžený cíl - bohatství, blahobyt.

Bohatství samo o sobě není špatné a je-li dobře spravováno a využíváno, může být požehnáním. Jenže př́liš často jej provází lakomství, a to je v křestanství smrtelný hřích, který stojí na druhém místě, hned za pýchou.

Blahobyt vede k nerozhodnosti a rozbředlosti celých národů (a především jejich politických elit) a k neschopnosti přijmout nutná, byt třeba bolestivá opatření. Skvěle to vystihl v roce 1936 Winston Churchill, který kritizoval neschopnost britské vlády čelit nebezpečí nacistického Německa:

Tato vláda se prostě nedokáže rozhodnout nebo přimět ministerského předsedu, aby tak učinil. Proto pokračují v tomto podivném paradoxu, rozhodnuti k nerozhodnosti, odhodláni k ničemu se neodhodlat, tvrdošíní ve své váhavosti, pevní v rozbředlosti, silní v bezmoci. ... Bliží se konec éry odkladů, polovičatých řešení, konejšivých a nesmyslných výmluv, zdržování. Namísto toho vstupujeme do období jejich důsledků.

Jaké bude, slovy W. Churchilla „období důsledkủ“? Chmurný scénáŕ budoucnosti, zejména v Africe, nastínil v roce 1994 Robert Kaplan ve výborné studii „Přicházející anarchie“, rozšiřrené později do podoby knižní publikace [Kaplan 2001]. Jeho varování je aktuální i po dvou desetiletích. Dle Kaplana základní faktory ovlivňující vývoj jsou ekologická vyčerpanost, kulturní a rasové kolize, geografická podmíněnost a proměny podoby války. Místem, kde se negativní působení těchto faktorů projevuje dnes nejzřetelněji, je Afrika, resp. oblast Guinejského zálivu. Tato část planety nabízí děsivý obraz chudoby, nemocí a vyčerpaných zdrojů. Je to region rozpadajících se národních států a mezinárodních hranic, rozmáhající se zločinnosti a permanentních kmenových válek. Za této situace vystupuje jako skutečné strategické nebezpečí nekontrolovatelný výbuch kriminální anarchie. Takový vývoj možná čeká zbytek Afriky a třetího světa. $\mathrm{V}$ těchto extrémně těžce ovladatelných zemích pak tlaky neústí $\mathrm{v}$ totalitarismus, ale v rozpad sociálních struktur a v „kulturu pouličních válečníkư“, jako např̀. v Somálsku. Přes kontinenty se přeženou vlny nepřehledných konfliktů bez jasného schématu, což pro Západ znamená, že nebude existovat žádná zjevná, jednoduše definovatelná hrozba, jakou byl komunismus nebo nacismus.

Takovýto vývoj může vést jen $\mathrm{k}$ diskreditaci ideálů demokracie a k volání po silném, autoritativním vládci. 


\section{Závěr: hledání „vůle ke smyslu“}

Jak na výše uvedené neradostné vyhlídky reagovat? Viktor E. Frankl ${ }^{9}$ [2006], zakladatel logoterapie, tvrdí, že základním zájmem člověka je jeho vůle ke smyslu (to znamená, že člověk sahá za sebe sama k nějakému smyslu). Opravdové úsilí po smyslu je podstatný aspekt lidské přirozenosti a sebetranscendence. Vưle ke smyslu je podle něj skutečně specifická potřeba neredukovatelná na jiné potřeby a je ve větším či menším stupni vlastní všem lidským bytostem. ${ }^{10}$

Pokud je vůle ke smyslu frustrována (potlačena), objevuje se „vůle k moci“ a/nebo „vưle ke slasti“. Čím více jde člověku o slast, tím více mu také uniká. Viktor Frankl tvrdí, že musíme překonat předsudek, že člověk usiluje v zásadě o to, aby byl štasten. Co ve skutečnosti chce, je to, aby $\mathrm{k}$ tomu měl důvod.

Zkusme se podívat závěrem na základní filozofickou otázku: „Kdo jsme? Odkud přicházíme? Kam směřujeme?" Jinými slovy, jaký je možný smysl a vyústění evolučního vývoje člověka na této Zemi?

Začalo to Velkým třeskem před 13 miliardami let a formováním neživé hmoty, které trvalo 9 miliard let. ${ }^{11}$ Pak, necelou miliardu let od vzniku planety Země, před 3, 85 miliardami let, došlo k první transgresi, neboli přerodu evoluce neživé hmoty v evoluci biologickou. Ta na Zemi probíhala a probíhá dosud, aniž by, přes četné otřesy a „katastrofy“ byla jedinkrát přerušena.

Život se vyvíjel po stránce "genové", to je v chromozomech zakódovaných informací (genech), které rúdí vývoj jednotlivce od oplodnění buňky až $\mathrm{k}$ dospělému jedinci. U vy̌ších živočichů pak tento vývoj pokračoval i po stránce „paragenetické“, kdy se nový jedinec musí nejprve učit od rodičů či druhové skupiny, jak přežít ve svém prostředí. ${ }^{12}$ Třetím stupněm je evoluce „metagenetická“, aplikovatelná jen u člověka.

Ve chvíli, kdy došlo k „procitnutí lidské mysli“, uskutečnila se druhá transgrese, tedy přerod evoluce biologické v evoluci kulturní (uskutečňovanou skrze člověka). Kulturní evoluce vede přes rozvoj nástrojů, používání ohně, zemědělství, architekturu, vynález písma, filozofii a vědu až $\mathrm{k}$ rychlé expanzi homosféry a následně noosféry. ${ }^{13} \mathrm{~V}$ noosféře dochází k závratně rychlému šíření informací, poznání a schopnosti komunikovat. Dosáhli jsme technologického stadia, kdy každý z nás může být identifikován v každém

9 Viktor E. Frankl (1905-1997) se narodil ve Vídni, jeho rodiče pocházeli z Čech. Byl profesorem neurologie a psychiatrie na univerzitě ve Vídni a profesorem logoterapie na univerzitě v Kalifornii. Přednášel na 175 univerzitách celého světa. Je zakladatelem logoterapie, neboli „třetího vídeňského směru psychoterapie“. Napsal více než 30 knih, které vyšly ve 25 jazycích, získal celkem 27 čestných doktorátů.

${ }_{10}$ V. Frankl [2006] cituje Annemarie von Forstmayerovou, která zjistila v $90 \%$ př́padů těžkého alkoholismu pocit hluboké bezesmyslnosti.

${ }_{11}$ Život mohl v jiné části vesmíru samozřejmě vzniknout podstatně dříve, než na Zemi, zatím však o životě mimo naši planetu nevíme.

${ }_{12}$ Např. mladý dravec se učí od rodičủ, jak chytat kořist. Platí, že čím vy̌̌ší organismus, tím delší „yýuka“ mladých.

13 Homosféra je definována př́tomností člověka a dosahem jeho vlivu. Homosféra je tedy sféra, kde člověk svou prítomností a vlivem převládá. Noosféra vzniká přeměnou biosféry silou lidské inteligence. Je to vlastně suma poznatků a informací nahromaděných lidským pokolením v průběhu historie. Těchto poznatků a informací člověk využíá, aby přeměňoval a proměňoval svoje životní prostředí (biosféru). 
okamžiku kdekoliv na světě. Žijeme ve fázi totální globalizace. Vyústění této situace může být dvojí. Bud' sebedestrukce nebo třetí transgrese a posun do dalšího stadia evoluce, do stadia spiritualizace.

$\mathrm{V}$ tomto stadiu (pokud bude člověk schopen do něj úspěšně vstoupit) by se měla uskutečnit bio-sociologická sebeorganizace lidstva, kdy člověk začne určovat a řídit svůj další vývoj. Po stránce biologické už první známky této sebeřízené evoluce můžeme vidět - umělé oplodňování, přenášení genů, eugenické manipulace. ${ }^{14}$ Dokud však mravní a duchovní proměna člověka nedostihne a nepředčí biotechnologickou evoluci, budeme v neustálém ohrožení fatálního zneužití svých schopností a z toho vyplývající sebedestrukce (a také destrukce světa, který nás obklopuje).

Je to skoro nepředstavitelné, ale jednou by mělo dojít k převaze „mysli nad hmotou“. Jinými slovy, k proměně (přetvoření) lidské přirozenosti. Možná, že právě toto je smyslem a konečným účelem předlouhého procesu proměn z minerální, resp. anorganické sféry (tedy ze sféry neživého fyzického světa) Alfa, přes biosféru (oživený svět), až ke sféře spiritualizace a čistého ducha Omega. Teilhard de Chardin ${ }^{15}$ nazývá dosažení bodu Omega ${ }^{16}$ konečným cílem vesmírné evoluce. [Svoboda, Nováček 2002]

Pro mne existuje jen jediný způsob, jak žít. Nabrat výšku, vystoupit tak vysoko, až se přes porodní chaos jednotlivostí, byt’ sebebolestivějších, otevře pohled na významnou pravidelnost určitého velkého údělu lidstva.

Pierre Teilhard de Chardin

\section{LITERATURA}

Barney, Gerald O. 1980. The Global 2000 Report to the President. Oxford: Pergamon Press.

Capra, Frithjof. 1982. The Turning Point: Science, Society, and the Rising Culture. New York: Simon and Schuster.

Daly, Herman E., John B. Cobb. 1989. For the Common Good. Redirecting the Economy toward Community, the Environment, and a Sustainable Future. Boston: Beacon Press.

Daly, Herman E. 1996. Beyond Growth. Boston: Beacon Press.

Frankl, Viktor. 2006. Vưle ke smyslu. Vybrané přednášky o logoterapii. Praha: Cesta.

Fromm, Erich. 1976. To Have or to Be? London: Abacus.

Funda, Otakar A. 2000. Znavená Evropa umírá. Praha: Karolinum.

Gabor, Denis et al. 1978. Beyond the Age of Waste. Oxford: Pergamon Press.

Glenn, Jerome C., Theodore J. Gordon., Elizabeth Florescu. 2011. State of the Future. Washington, D.C.: Millennium Project.

Hawrylyshyn, Bohdan. 1980. Road Maps to the Future. Towards More Effective Societies. Oxford: Pergamon Press.

Kalous, Jaroslav. 2006. Vývoj světa. Praha: Centrum pro sociální a ekonomické strategie Fakulty sociálních věd Univerzity Karlovy (interní materiál), $24 \mathrm{~s}$.

14 Eugenika je sociálně-filozofický směr zaměřený na studium metod, které povedou k dosažení co nejlepšího genetického fondu člověka.

15 Pierre Teilhard de Chardin (1881-1955) byl jezuita, vědeckou profesí geolog a paleontolog. Ve svém významném díle „Vesmír a lidstvo“ [1990] přináší originální syntézu biblické představy Stvoření a konce světa s evolučním pojetím vývoje.

16 Připomeňme si zde biblický výrok ze Zjevení Janova: „Já jsem Alfa i Omega, první i poslední, počátek i konec." $[\mathrm{Zj} 22,13]$ 
Kalous, Jaroslav. 2008. Opice na Titaniku. Mscr., 31 s.

Kaplan, Robert D. 2001. The Coming Anarchy: Shattering the Dreams of the Post Cold War. New York: Vintage.

Kysučan, Lubor. 1997. Na zlomu času. Olomouc: Vydavatelství University Palackého.

László, Ervin, et al. 1977. Goals for Mankind. New York: Dutton.

Lewis, Clive S. 1993. K jádru křestanství. Praha: Návrat domů.

Lovelock, James. 1979. Gaia: A New Look at Life on Earth. Oxford: Oxford University Press.

Maslow, Abraham H. 1954. Motivation and Personality. London: HarperCollins.

Meadows, Donella H., Dennis L. Meadows, Jorgen Randers. 1972. The Limits to Growth. New York: Universe Books. A Potomac Associates Book.

Mederly, Peter, Ján Topercer, Pavel Nováček. 2004. Indikátory kvality života a udržitelného rozvoje kvantitativní, vícerozměrný a variantní prístup. Praha: Centrum pro sociální a ekonomické strategie FSV UK.

Mesarovic, Mihajlo, Edward Pestel. 1976. Mankind at the Turning Point. New York: Dutton.

Nováček, Pavel, Peter Mederly a kol. 1996. Strategie udržitelného rozvoje. Praha: G plus G.

Popper Karl R. 1996. Otevřená společnost a její neprrátelé. ISE: Praha.

Putnam, Hilary, Richard Rorty. 1997. Co po metafyzice? (Hilary Putnam a Richard Rorty o realismu a relativismu.) Bratislava: Archa.

Rynda, Ivan. 2000. „Trvale udržitelný rozvoj.“ Geografické rozhledy 10 (1): 10-11.

Schumacher, Ernst F. 1973. Small is Beautiful. A Study of Economics as if People Mattered. London: Blond and Briggs.

Smelser, Neil J. 1994. Sociology. Cambridge: Blackwell.

Svoboda, Josef, Pavel Nováček. 2002. Rozhovory od Bakerova jezera. Na hranici reality, meta-reality a fikce. Luhačovice: Atelier IM.

Teilhard de Chardin, Pierre. 1990. Vesmír a lidstvo. Vyšehrad: Praha.

The World Commission on Environment and Development. 1987. Our Common Future. Oxford: Oxford University Press.

Tinbergen, Jan. 1976. RIO Report: Reshaping the International Order. New York: Dutton.

Toffler, Alvin. 1980. The Third Wave. New York: Bantam Books.

Vavroušek, Josef. 1993. „Perspektivy lidských hodnot slučitelných s trvale udržitelným způsobem života.“ Pp. 91-100 in Pavel Nováček, Josef Vavroušek (eds.). Lidské hodnoty a trvale udržitelný zpưsob života. Olomouc: Společnost pro trvale udržitelný život a Př́rodovědecká fakulta Univerzity Palackého.

\section{SUMMARY}

More than forty years ago Man landed on the Moon. On the other hand people in poor countries are starving to death until now. The environment is degraded or even devastated in many regions, biodiversity is decreasing. We need a daring vision of what to do next. And maybe more than that. We need to search for and find "will to meaning" (according to founder of logotherapy, Viktor Frankl).

Almost 25 years ago vision of sustainable development was first published in the UN report "Our Common Future". Question remains, how vital and perspective is this vision in present multipolar world.

In the past we learned from our former experience and mistakes. Today, in the era of huge scientific and technological development, we need new model of learning. We need to learn from our future potential opportunities as well as threats, not just from the past.

It also includes possibility, that our effort to formulate and implement sustainable development will not succeed. Then alternative to sustainable development is sustainable retreat. And even darker scenario is possible - chaos and anarchy. We can already see this in some failed states (Somalia, Haiti). In such case key challenge would be to keep and preserve principal knowledge and skills accumulated by civilized societes during former decades and centuries for future generations. 